\title{
Manajemen Pembelajaran pada Mata Pelajaran PAI untuk Anak Autis di Tingkat Sekolah Dasar
}

\author{
Afif Kholidin \\ IAIN Kudus, Kudus, Indonesia \\ kholidin.afif@gmail.com \\ Mas'ad \\ IAIN Kudus, Kudus, Indonesia \\ masadmakruf@gmail.com
}

\begin{abstract}
This research aim know the management of PAI learning for autistic children in SDLB Sunan Kudus. This type of research is a qualitative descriptive research. The data collection techniques apply observation, interview, and documentation. From the data obtained, analysed by using the triangulation method. The findings of this research are the management applying of PAI learning for autistic children that showed by planning which prepared everyday and in accordance with the preparing procedure of PPI. The next, organizing of planning that has been prepared by providing resources who complement autistic children's needs and adapting to their conditions. And than, organize the existing resources into PAI learning by importing simplified material and adapted to the conditions of autistic children in their daily lives. The evaluation of PAI learning is use the process evaluation and products evaluation during the learning is going on continuously with giving descriptive notes value.
\end{abstract}

Keywords: Management; Learning; PAI; Children; Autism 


\begin{abstract}
Abstrak
Penelitian bertujuan untuk memperoleh gambaran mengenai manajemen pembelajaran pada mapel PAI yang diterapkan khusus pada anak autis di SDLB Sunan Kudus. Jenis penelitian ini adalah penelitian deskriptif kualitatif. Teknik pengumpulan data yang diterapkan adalah teknik observasi, wawancara, dan dokumentasi. Dari data yang diperoleh kemudian dilakukan analisis dengan metode triangulasi. Adapun temuan penelitian ini adalah manajemen pembelajaran PAI yang diterapkan secara khusus pada anak autis ditunjukkan dengan perencanaan yang disusun setiap hari dan sesuai dengan prosedur penyusunan PPI. Perencanaan yang sudah disusun dilakukan pengorganisasian dengan menyediakan sumber daya yang memenuhi kebutuhan dan sesuai dengan kondisi mereka. Dari sumber daya yang ada diorganisasikan ke dalam pembelajaran PAI dengan cara memasukkan materi PAI yang sudah disederhanakan dan disesuaikan dengan kondisi anak-anak autis ke dalam kegiatan sehari-hari. Evaluasi pembelajaran PAI melalui tahap evaluasi proses dan evaluasi produk yang dilakukan pada saat pembelajaran berlangsung secara terus-menerus dengan memberikan nilai dalam bentuk catatan deskriptif.
\end{abstract}

Kata kunci: Manajemen; Pembelajaran; PAI; Anak; Autis

\title{
A. Pendahuluan
}

Manajemen pembelajaran merupakan upaya mencapai pembelajaran yang efektifk dan efisien dengan menerapkan fungsi-fungsi manajemen dalam kegiatan pembelajaran. Fungsi-fungsi tersebut setidaknya terdiri dari tiga kegiatan, yaitu perencanaan, pelaksanaan dan evaluasi pembelajaran (Suhendri, 2017, p. 53-54). Seorang guru harus mampu mengelola pembelajaran agar mencapai suasana pembelajaran yang kondusif, mengembangkan interaksi yang positif antara guru dan peserta didik, serta menciptakan dan menjaga organisasi kelas yang efektif untuk mendukung perkembangan peserta didik sesuai dengan tujuan pembelajaran dan mengurangi perilaku yang tidak sesuai (Erwinsyah, 2017, p. 73).

Beberapa tahap dalam perencanaan pembelajarn adalah pemilihan, penetapan, dan pengembangan perangkat pembelajaran (pendekatan, metode, teknik, bahan ajar, pengetahuan dan pengalaman, dan alat ealuasi untuk mengukur tingkat keberhasilan pembelajaran (Puspitasari, 2017, p. 346-347). Setelah melakukan perencanaan guru melakukan pengorganisasian pembelajaran agar rencana yang telah disusun tidak menjadi kerja yang sia-sia. Organisasi pembelajaran dilakukan untuk menentukan dan menyusun materi pembelajaran, menyiapkan alat, bahan, dan media pembelajaran, menyiapkan instrumen pemberian tugas kepada peserta didik baik individu maupun 
kelompok, serta menenrtukan tanggungjawab yang akan diberikan kepada peserta didik dalam proses pembelajaran. Sedangkan pada tahap penilaian pembelajaran guru mengaplikasikan penilaian otentik untuk mengetahui kesiapan, proses belajar, dan hasil belajar peserta didik (Musdalifa \& Panu, 2019, p. 125-126).

Pembelajaran dikatakan efektif apabila dapat membangun persepsi dan sikap peserta didik yang baik sehingga mampu memfasilitasi proses pembelajaran, membantu peserta didik memperoleh ilmu pengetahuan dan mampu mengintegrasikan dan mengembangkannya melalui pengalaman, serta memnciptakan karakter peserta didik yang mampu menerapkan ilmu pengetahuan dan terbiasa berpikir positif (Thomas, 2011, p. 18). Untuk mencapai hasil tersebut guru harus menerapkan manajemen pembelajaran dalam melaksanakan proses pembelajaran. Dengan menerapkan manajemen pembelajaran guru mampu mengendalikan proses pembelajaran demi mencapai tujuan pembelajaran secara lebih efektif, efisien, dan produktif. Atau bisa dikatakan manajemen pembelajaran membantu mencapai tujuan pembelajaran secara lebih efektif, efisien, dan produktif (Efendy, 2018, p. 1002).

Sedangkan pelaksanaan pembelajaran pada anak autis sangat sulit dikendalikan, terutama pada mata pelajaran PAI yang banyak menggunakan cara berpikir abstrak. Berdasarkan hasil sebuah penelitian, terdapat banyak faktor yang menghambat efektivitas pembelajaran PAI pada anak autis. Tantrum pada anak autis mengakibatkan penyimpangan pada perkembangan sosial, kemampuan berkomunikasi, dan berinteraksi dengan lingkungan sekitar, sehingga sangat sulit membawa anak autis masuk ke dalam pembelajaran dan memahami materi pembelajaran. Gangguan pada fungsi otak menjadikan anak autis kesulitan dalam memahami materi pembelajaran (Ballerina, 2017, p. 247). Selain problem tersebut, terdapat beberapa problem lain yang mempengaruhi efektivitas pembelajaran pada anak autis, di antaranya tidak ada kurikulum khusus mengenai pembelajaran agama Islam, belum adanya pegangan khusus mengenai pelaksanaan pembelajarana PAI, kesulitan dalam memperoleh guru PAI yang berlatarbelakang pendidikan guru PAI anak autis, kekurangan media pembelajaran PAI dan strategi pemelajaran PAI pada anak autis, serta keterbatasan waktu pembelajaran PAI (Hanum, 2014, p. 220).

Peneliti menemukan bahwa dalam satu kelas usia peserta didik bervariasi dan perbedaannya sangat signifikan, masing-masing mempunyai keunikan dan tingkat gangguan sendiri-sendiri yang menjadikan setiap peserta didik membutuhkan penanganan yang berbeda-beda, ada yang antusias mengikuti instruksi guru, ada yang belum bisa memokuskan konsentrasinya ke dalam pembelajaran, dan juga terdapat peserta didik yang sibuk dengan aktivitasnya sendiri dan sama sekali tidak bisa memperhatikan pembelajaran. Kekurangan jumlah pendamping menjadikan guru 
pendamping kesulitan dalam mengondisikan peserta didik yang sebagian besar membutuhkan perhatian khusus dan intens, yang mengakibatkan tidak semua peserta didik dengan segera masuk ke dalam pembelajaran, di antara mereka ada yang tidak memperhatikan pembelajaran ketika perhatian guru pendamping memerhatikan peserta didik lain (Peneliti, Observasi, 13 Januari 2019).

Menurut Kepala SDLB Sunan Kudus, pelaksanaan pembelajaran di SDLB Sunan Kudus tidak bisa sepenuhnya dilaksanakan sesuai dengan perencanaan yang telah ditetapkan. Hal tersebut dikarenakan kondisi individu peserta didik autis setiap saat bisa berubah, sehingga pelaksanaan pembelajaran pada anak autis di SDLB Sunan Kudus disesuaikan dengan kondisi anak-anak autis pada saat pembelajaran. Materi yang diajarkan juga tidak bisa sesuai dengan standar anak normal karena porsi pembelajaran anak autis berbeda, sehingga guru harus menyesuaikan materi dengan kondisi anak autis (Kristianto, Wawancara, 11 Maret 2020).

Dalam melaksanakan penelitian ini, terlebih dahulu peneliti melakukan telaah terhadap hasil penelitian yang sebelumnya ditemukan oleh peneliti lain untuk kemudian dilakukan perbandingan, agar tidak terjadi kemiripan atau pengulangan pembahasan. Adapun penelitian terdahulu yang dijadikan pertimbangan oleh peneliti di antaranya adalah Problematika Pembelajaran Pendidikan Agama Islam bagi Siswa Autis, yang ditulis oleh Hayyan Ahmad Ulul Albab dalam jurnal Akademika pada tahun 2015. Jurnal tersebut membahas masalah-masalah yang dihadapi guru dalam proses pembelajaran pada mapel PAI untuk peserta didik autis di salah satu SMA di Surabaya dan upaya yang dilakukan guru untuk mengatasi masalah tersebut (Albab, 2015, p. 202). Letak perbedaannya adalah penelitian ini mengkaji seluruh unsur-unsur manajemen pembelajaran pada mapel PAI bagi peserta didik autis dan bukan hanya problematikanya saja, sehingga pembahasannya lebih pada proses mengelola pembelajaran PAI pada anak autis demi mencapai tujuan secara efektif dan efisien. Penelitian kedua berjudul Manajemen Pembelajaran PAI bagi Anak Berkebutuhan Khusus di SLB Kota Medan, oleh Suhendri dalam Jurnal Sabilurrasyad tahun 2017. Penelitian tersebut membahas manajemen pembelajaran PAI pada ABK secara umum (Suhendri, 2017, p. 45). Perbedaannya penelitian ini lebih khusus membahas manajemen pembelajaran PAI bagi anak penyandang autis yang memiliki gangguan mental dan memiliki individualitas yang sangat unik antara satu dengan yang lainnya, sehingga problematika yang dihadapi pendidik berbeda dengan ABK yang secara umum gangguannya terletak pada fisik dan bukan psikis. Sedangkan penelitian ketiga adalah Hubungan Dukungan Sosial dengan Kemampuan Sosialisasi Anak Autisme di Yayasan Pondok Pesantren ABK al-Achsaniyyah Kudus Tahun 2017. Penelitian tersebut dilakukan oleh Yulisetyaningrum dan lainnya dalam Jurnal Ilmu Keperawatan dan 
Kebidanan pada Tahun 2018. Penelitian tersebut memperoleh hasil bahwa terdapat hubungan yang signifikan antara dukungan sosial dengan kemampuan sosialisasi anak autis di yayasan pondok pesantren ABK al-Achsaniyyah Kudus tahun (Yulisetyaningrum et al., 2018, p. 44). Meskipun lokasi dan subjek penelitian sama, tapi keduanya memiliki perbedaan. Penelitian tersebut lebih fokus meneliti korelasi dukungan sosial dengan kemampuan sosial anak autis, sedangkan penelitian yang peneliti lakukan membahas upaya guru PAI dalam mengelola pembelajaran agar mencapai tujuan yang diharapkan.

Penelitian ini termasuk ke dalam penelitian lapangan (field research), yaitu penelitian secara perinci yang lebih bersifat teknis dengan penekanan pada interaksi dengan subjek penelitian di SDLB Sunan Kudus dan deskripsi terhadap manajemen pembelajaran mapel PAI pada anak autis yang bersifat apa adanya (given) sehingga memberikan gambaran yang luas serta mendalam. Adapun pendekatan dalam penelitian ini, peneliti menggunakan pendekatan kualitatif (qualitative research) untuk mendeskripsikan situasi sosial yang sebenarnya mengenai manajemen pembelajaran pada mapel PAI bagi anak autis di SDLB Sunan Kudus, sehingga penyajian datanya berupa catatan dengan deskripsi kalimat yang perinci, lengkap, mendalam yang menggambarkan situasi yang sebenarnya. Penelitian ini lebih cenderung membahas cara mengelola pembelajaran PAI pada anak autis, berbeda dengan penelitian-penelitian terdahulu yang membahas manajemen pembelajaran pada anak normal atau membahas tentang masalah yang muncul dalam pelaksanaan pembelajaran pada anak autis dan solusinya. Penelitian ini membahas tentang cara mengelola pembelajaran PAI pada anak autis untuk menghindari munculnya problem-problem yang akan menghambat efektivitas pembelajaran PAI dan mampu mencapai tujuan pembelajaran. Penelitian ini dilaksanakan dengan tujuan untuk mengetahui perencanaan pembelajaran PAI, pengorganisasian pembelajaran PAI, dan evaluasi pembelajaran pada mapel PAI bagi anak autis. Penelitian ini dilakukan karena sampai saat ini belum ada penelitian yang secara khusus membahas manajemen pembelajaran PAI pada anak autis.

Oleh karena itu peneliti melakukan penelitian tentang manajemen pembelajaran pada mapel PAI bagi peserta didik autis di SDLB Sunan Kudus untuk menjawab tentang bagaimana perencanaan pembelajaran PAI pada anak autis? Bagaimana pengorganisasian pembelajaran PAI pada anak autis? Dan bagaimana evaluasi pembelajaran PAI pada anak autis?

\section{B. Pembahasan}

\section{Kepemimpinan Perencanaan Pembelajaran Mapel PAI untuk Anak Autis}


Manajemen pembelajaran PAI pada anak autis berarti pemberdayaan fungsi perencananaan, pengorganisasian, dan evaluasi dalam pembelajaran pada mapel PAI untuk mencapai goal yang telah ditetapkan secara efektif dan efisien untuk peserta didik yang mengalami gangguan perkembangan mental disebabkan oleh kelainan sistem saraf atau trauma eksternal yang mengakibatkan kesulitan dalam berkomunikasi dan berinteraksi sosial.

Sedangkan fungsi perencanaan pembelajaran di SDLB Sunan Kudus dilakukan untuk menyiapkan bahan ajar, tujuan pembelajaran, metode pembelajaran, pendekatan pembelajaran, media pembelajaran, serta evaluasi pembelajaran yang disesuaikan dengan keadaan peserta didik autis yang sedang ditangani (Peneliti, Dokumentasi, 12 Maret 2020). Hal tersebut sesuai dengan Puspitasari yang menjelaskan bahwa perencanaan pembelajaran dilakukan untuk memilih, menetapkan, dan mengembangkan tujuan, metode, pendekatan, bahan, dan media pembelajaran, serta menyiapkan evaluasi untuk mengukur tingkat keberhasilan dalam mencapai tujuan pembelajaran (Puspitasari, 2017, p. 346). Perencanaan pembelajaran pada mapel PAI bagi anak autis di SDLB Sunan Kudus disesuaikan dengan Permendikbud Nomor 22 Tahun 2016, yaitu terdiri atas penyusunan perangkat pembelajaran, pemilihan sumber belajar, dan rancangan evaluasi pembelajaran (Peneliti, Dokumentasi, 12 Maret 2020).

Berdasarkan hasil observasil, dalam pelaksanaan pembelajaran mapel PAI bagi anak autis di SDLB Sunan Kudus tetap dilakukan perencanaan dengan menyiapkan jurnal harian guru mengajar yang digunakan sebagai acuan dalam melaksanakan kegiatan belajar-mengajar yang disertai dengan format penilaian. Jurnal harian juru mengajar fungsinya sama dengan RPP, namun dilakukan modifikasi baik pada kegiatan pembelajaran maupun sistem evaluasinya (Peneliti, Observasi, 3 Februari 2020).

Kepala SDLB Sunan Kudus dan guru di kelas besar menjelaskan bahwa SDLB Sunan Kudus melakukan perencanaan seperti membuat kalender pendidikan, silabus, dan RPP yang menurut pihak SDLB disebut jurnal harian mengajar, tapi guru tidak bisa menerapkan sepenuhnya sesuai dengan yang telah direncanakan. Hal tersebut disebabkan kondisi anak-anak autis yang setiap saat bisa berubah, kadang baik dan tenang, kadang bisa saja hiperaktif bahkan ada yang tidak mau belajar, sehingga penerapannya dikembangkan dan disesuaikan dengan perkembangan peserta didik (Kristianto, Wawancara, 11 Maret 2020 dan Charisma, Wawancara, 21 Januari 2020). Menurut penjelasan guru kelas, perencanaan pembelajaran di SDLB tersebut disesuaikan dengan standar dari Pemerintah untuk memenuhi tuntutan yang telah ditetapkan, sedangkan pembelajaran bagi peserta didik autis tidak dapat disamakan dengan pembelajaran pada peserta didik pada umumnya. Perkembangan peserta didik autis lebih lambat dibandingkan peserta didik normal, sehingga materi yang 
disampaikan harus sesuai kemampuan mereka dan membutuhkan waktu yang lebih lambat. Guru kelas menyiapkan beberapa perangkat pendukung dalam menangani anak autis, seperti menyiapkan alat perekaman perkembangan peserta didik yang kemudian dilakukan perekapan setiap seminggu sekali dan ditentukam tujuan pencapaian kemampuan yang akan diajarkan dalam seminggu berikutnya (Charisma, Wawancara, 21 Januari 2020).

Sedangkan Kepala SDLB Sunan Kudus menyampaikan bahwa pelaksanaan pembelajaran di SDLB Sunan Kudus diintegrasikan antara model pembelajaran yang sesuai dengan standar pemerintah dan model pembelajaran hasil pengembangan guru di SDLB Sunan Kudus, yaitu dengan menyediakan kelas tambahan sebagai kelas pembinaan bagi peserta didik autis. Kelas tambahan dilaksanakan di ruang kecil dengan satu guru menangani satu peserta didik, dalam istilah SDLB Sunan Kudus disebut sebagai kelas kecil. Pelaksanaan pembelajaran di kelas kecil dilakukan secara individual (Kristianto, Wawancara, 11 Maret 2020).

Menurut idealnya pembelajaran pada anak autis dilaksanakan dengan menerapkan Program Pembelajaran Individual (PPI), yaitu kurikulum nasional yang dilakukan pengembangan dengan menerapkan pendekatan individual dan disesuaikan dengan karakteristik, kemampuan, dan kebutuhan setiap peserta didik autis yang berbeda-beda antara individu dengan individu lainnya. Penyusunan PPI dimaksudkan untuk dijadikan guru sebagai alat dalam menggali informasi tentang mendesain pembelajaran yang mendukung peserta didik autis (Mardiana et al., 2020, p. 180). Penyusunan perangkat pembelajaran secara kolektif dapat mengakibatkan ketidaksesuaian pada beberapa peserta didik, maksudnya beberapa peserta didik mungkin bisa mengikuti namun yang lainnya ketinggalan. Hal tersebut akan berdampak pada terhambatnya efektivitas dan efisiensi pencapaian tujuan pembelajaran.

Berdasarkan hasil observasi, pemilihan materi PAI yang diajarkan di SDLB Sunan Kudus merupakan penerapan Peraturan Menteri Agama No. 912 Tahun 2013, namun dilakukan penyederhanaan pada muatan-muatan materi dan pengembangan model pembelajaran, di antaranya berupa memasukkan materi PAI seperti membaca alAsmā' al-Husnā, doa-doa harian, menyanyikan rukun Islam, menghafal juz 30, dan yang lainnya (Peneliti, Observasi, 6 februari 2020). Hal tersebut dilakukan guru karena mempertimbangkan keadaan dan kemampuan peserta didik autis yang memiliki kesulitan dalam berpikir abstrak, sesuai dengan salah satu fungsi guru yang dijelaskan Permendikbud Nomor 22 tahun 2016, bahwa guru bertugas menyesuaikan materi pelajaran dengan kecepatan dan kemampuan belajar peserta didik. 
Pembelajaran PAI di SDLB Sunan Kudus dilaksanakan dengan cara memasukkan materi PAI setiap hari, seperti berdoa sebelum membuka pembelajaran, membaca al-Asmā' al-Ḥusnā bersama-sama guru kelas dan guru pendamping, menyanyikan lagu rukun Islam di sela-sela pembelajaran, dan membaca doa setelah selesai pelajaran (Peneliti, Observasi, 6 februari 2020). Berdasakan penjelasan dari pihak SDLB Sunan Kudus muatan materi PAI dimasukkan ke dalam pembelajaran dengan alokasi waktu 1 (satu) jam per hari setiap pagi, seperti berdoa dan melafalkan alAsmā' al-Ḥusnā dan setiap ganti pelajaran guru mengajak peserta didik membaca doa penutup atau menyanyikan materi agama (Kristianto, Wawancara, 11 Maret 2020). Hal tersebut setidaknya sudah memenuhi standar dari Pemerintah dalam PMA. No. 912 Tahun 2013. Alasan penyederhanaan materi PAI dan pengembangan metode dan pendekatan pembelajaran pada anak autis dilakukan karena melaksanakan pembelajaran pada anak autis lebih susah daripada anak normal. Anak-anak autis lebih mudah menerima materi dengan cara memberi contoh dan instruksi secara berulang-ulang sehingga mampu membiasakan diri mereka menerapkan materi PAI dalam kegiatan sehari-hari (Charisma, Wawancara, 21 Januari 2020). Alasan tersebut bertepatan dengan penelitian Ardina dalam mengajar peserta didik autis lebih efektif menggunakan metode ABA yaitu metode tatalaksana perilaku yang menerapkan prosedur perubahan perilaku, hal tersebut dapat meningkatkan kepatuhan pada anak autis agar peserta didik autis layak hidup di tengah-tengah masyarakat dan memiliki kemampuan (Ardina, 2018, p. 90).

Perencenaaan sistem evaluasi di SDLB sunan Kudus dilaksanakan bersamaan dengan penyusunan perangkat pembelajaran. Dalam menyiapkan penilaian pembelajaran untuk peserta didik autis guru kelas menyiapkan beberapa instrumen penilaian, di antaranya alat perekaman perkembangan peserta didik yang kemudian dilakukan perekapan setiap seminggu sekali dan ditentukam tujuan pencapaian kemampuan yang akan diajarkan dalam seminggu berikutnya (Peneliti, Dokumentasi, 12 Maret 2020). Di SDLB Sunan Kudus, penilaian pada peserta didik autis dilakukan setiap hari dan direkap setiap minggunya dimaksudkan agar perkembangan peserta didik autis dapat termonitor secara lebih akurat. Setelah memperoleh hasil evaluasi selama 1 (satu) minggu pembelajaran, guru membuat rencana pembelajaran untuk seminggu berikutnya agar mudah menyesuaikan dengan kondisi peserta didik autis pada saat pembelajaran berlangsung. Di dalam merencanakan penilaian pembelajaran pada mapel PAI, guru di SDLB Sunan Kudus menentukan metode penilaian dan bentuk nilai yang diberikan kepada peserta didik (Kristianto, Wawancara, 11 Maret 2020 dan Charisma, Wawancara, 21 Januari 2020). Hal tersebut sesuai dengan Rahmi dalam Widyawati bahwa guru sebaiknya mengenali kemampuan awal setiap peserta didik autis 
secara intensif dan karakteristik mereka sehingga setiap individu mendapat perhatian dan perlakuan yang tepat (Widyawati, 2017, p. 116).

\section{Pengorganisasian Pembelajaran Mapel PAI untuk Anak Autis}

Pengorganisasian pembelajaran di SDLB Sunan Kudus dilaksanakan demi menghimpun sumber daya pembelajaran serta mengatur dan memanfaatkannya seefektif dan seefisien mungkin agar pelaksanaan pembelajaran mampu meraih tujuannya. Pengorganisasian yang dilakukan SDLB Sunan Kudus di antaranya adalah pengorganisasian sumber daya pembelajaran, pengelolaan kelas, dan proses pembelajaran (Kristianto, Wawancara, 11 Maret 2020).

Pembelajaran pada mapel PAI bagi anak autis di SDLB Sunan Kudus diselenggarakan dengan mengacu pada Peraturan Menteri Pendidikan dan Kebudayaan Nomor 65 Tahun 2013, tentang Standar Proses Pendidikan Dasar dan Menengah, namun Pemerintah hanya menentukan standar untuk peserta didik normal, sedangkan Pemerintah tidak memberikan standar khusus untuk peserta didik autis sehingga guru SDLB Sunan Kudus melakukan modifikasi sendiri agar mampu melaksanakan pembelajaran yang efektif pada anak autis (Charisma, Wawancara, 21 Januari 2020).

Di SDLB Sunan Kudus, kurikulum pembelajaran pada mapel PAI didasarkan atas kurikulum nasional yaitu kurikulum 2013. Pembelajaran PAI bertujuan untuk membentuk generasi yang berakhlakul karimah, sebagaimana dijelaskan dalam Peraturan Pemerintah Nomor 32 Tahun 2013 dan Peraturan Menteri Agama Nomor 912 Tahun Tahun 2013. Akan tetapi dalam penerapannya dilakukan penyesuaian seperti pemilihan metode, pendekatan, media dan sistem penilaian pembelajaran yang sesuai dengan kemampuan, karakteristik, dan kebutuhan peserta didik autis, serta penyederhanaan materi dan penyesuaian alokasi waktu (Kristianto, Wawancara, 11 Maret 2020). Pemuatan materi PAI tidak dilaksanakan dengan cara mengajarkan hal-hal abstrak yang tidak dapat dicontohkan secara fisik, namun dengan cara membiasakan diri melakukan hal-hal yang diajarkan sehingga peserta didik mampu mengerjakan sesuatu yang menjadi materi pembelajaran PAI dengan mandiri (Peneliti, Observasi, 6 februari 2020).

SDLB Sunan Kudus melaksanakan pembelajaran dengan memanfaatkan media pembelajaran yang mampu memenuhi kebutuhan peserta didik autis, di antaranya gambar-gambar, audio-visual, dan benda-benda instruksional lqainnya (Peneliti, Observasi, 6 februari 2020). Hal tersebut sesuai dengan penjelasan Rahmahtrisilvia bahwa pembelajaran pada peserta didik autis harus mempertimbangkan karakteristik dan kemampuan mereka. Beberapa karakteristik belajar anak autis di antaranya ada 
anak yang cenderung menghafalkan informasi apa adanya tanpa memahami arti dari informasi yang mereka hafalkan tersebut, ada anak yang cenderung belajar dengan cara menangkap informasi secara keseluruhan dan mengulangi kalimat secara kesuluruhan tanpa mampu menganalisisnya, ada yang senang mencoba dan belajar dari pengalaman, ada yang lebih mudah memahami informasi visual daripada yang hanya suara, serta ada anak autis yang lebih suka mendengarkan orang berbicara dan senang bicara (Rahmahtrisilvia, 2010, pp. 7-8).

Pembelajaran PAI pada anak autis di SDLB Sunan Kudus menerapkan gabungan antara pembelajaran kelas reguler dan pembelajaran kelas terapis. Pembelajaran reguler dilaksanakan sebagaimana kelas pada umumnya, yaitu 2 orang guru mengajar beberapa peserta didik dalam satu kelompok besar sehingga disebut juga sebagai kelasa besar. Sedangkan pembelajaran di kelas terapis dilakukan dengan skala yang lebih kecil, yaitu 1 guru mengajar 1 peserta didik sehingga disebut kelas kecil (Kristianto, Wawancara, 11 Maret 2020). Pembelajaran di kelas kecil menggunakan pendekatan individual agar perhatian terhadap individualitas peserta didik autis lebih intensif (Setyaningsih. Wawancaram, 11 Maret 2020), sesuai dengan Program Pembelajaran Individual (PPI) (Garnida, 2015, p. 107-108).

Proses belajar mengajar di kelas besar SDLB Sunan Kudus dimulai pada pukul 07.00 (tujuh pagi) dan berakhir pada pukul 13.00 (satu siang) WIB. Peserta didik tidak diwajibkan memakai seragam, akan tetapi peserta didik autis diperbolehkan memakai pakaian bebas namun sopan, dengan alasan kenyamanan peserta didik autis lebih diutamakan karena jika pakaian yang dikenakan peserta didik autis tidak membuat mereka nyaman konsentrasi peserta didik autis menjadi terganggu (Peneliti, Observasi, 6 Februari 2020), sebagaimana dalam Dewi dan lainnya yang menjelaskan bahwa anak autis menyukai rutinitas yang dilakukan terus-menerus tanpa berpikir dan jika dilarang dapat menimbulkan pengaruh buruk dan membuat marah (Dewi et al., 2018, p. 291). Ruang kelas di kelas besar SDLB Sunan Kudus didesain senyaman mungkin bagi peserta didik autis, ruang kelas diusahakan harus bersih dari benda-benda yang tidak akan digunakan dalam pembelajaran maupun orang-orang yang dapat mengganggu konsentrasi belajar mereka, sehingga dapat menjaga konsentrasi peserta didik autis agar mereka yang cenderung sulit mengontrol perhatian mampu memfokuskan perhatian mereka pada pembelajaran (Peneliti, Observasi, 6 Februari 2020). Hal tersebut dilakukan karena pada umumnya anak-anak autis memiliki sikap yang cenderung menolak berkomunikasi dan berinteraksi, seolah mereka hidup dalam dunia mereka masing-masing, serta memiliki kesulitan dalam mengalihkan perhatian, terutama ketika mereka telah memerhatikan sesuatu yang mereka senangi (Albab, 2015, p. 206-207). Ketika peserta didik autis tidak dapat mengikuti pembelajaran, maksudnya tidak fokus 
dalam pembelajaran di kelas besar maka peserta didik autis tersebut ditangani dengan pendekatan individual ij hdi kelas kecil untuk diberikan pembelajaran khusus (one on one). Kelas kecil didesain dengan ruang kelas yang lebih kecil dari kelas besar dan bersih dari benda-benda ataupun orang yang dapat mengganggu konsentrasi peserta didik autis (Kristianto, Wawancara, 11 Maret 2020 dan Setyaningsih, Wawancara, 11 Maret 2020).

Kegiatan pembelajaran di SDLB Sunan Kudus adalah pelaksanaan dari perencanaan, meskipun pelaksanaannya tidak sepenuhnya dapat diterapkan, namun tetap mencakup 3 kegiatan yaitu pendahuluan, inti, dan penutup sebagaimana standar yang dari Pemerintah dalam Permendikbud Nomor 22 tahun 2016 (Peneliti, Observasi, 6 Februari 2020).

Adapun tahapan-tahapan yang dilakukan guru dalam kegiatan pendahuluan pembelajaran pada anak autis di kelas reguler SDLB Sunan Kudus menurut salah seorang guru adalah: (1) Mengordinasikan peserta didik autis sebelum kegiatan belajar mengajar berlangsung baik psikis dan fisik. (2) Mengorganisasikan peserta didik setelah peserta didik masuk ke dalam ruang. (3) Mengucapkan salam dan mengajak peserta didik membaca al-Asmā' al-Husnā dan doa, serta melakukan pengecekan kondisi peserta didik (Charisma, Wawancara, 21 Januari 2020).

Sedangkan kegiatan-kegiatan pendahuluan yang dilakukan guru terapis di kelas kecil SDLB Sunan Kudus adalah: (1) Menjemput peserta didik. (2) Mengajak peserta didik untuk berdoa. (3) Mengucapkan salam pembuka. (4) Berinteraksi dengan cara memberikan pertanyaan (Setyaningsih, Wawancara, 11 Maret 2020).

Sesuai dengan hasil pengamatan terhadap kegiatan pembelajaran di SDLB Sunan Kudus kelas 6, kegiatan inti dalam pembelajaran di SDLB Sunan Kudus menyesuaikan kondisi, individualitas, dan kebutuhan peserta didik autis. Kompetensi dan materinya sudah disederhakana, yaitu difokuskan pada kemampuan dasar setiap individu autis baik. Materi PAI yang diajarkan masih seputar materi-materi dasar seperti doa harian, juz 30, salat, dan wudu (Peneliti, Observasi, 6 Februari 2020).

Metode dan media yang digunakan adalah beberapa metode yang dikombinasikan dan disesuaikan terhadap kebutuhan dan karakteristik peserta didik autis, di antaranya adalah metode ceramah, tanya jawab, demontrasi, dan metode dril (Peneliti, Observasi, 6 Februari 2020). Sebagaimana penjelasan Sopandi bahwa sekolah inklusi harus kohesif, menerima, dan cekat dalam merespon kebutuhan peserta didik. Dengan kata lain pendidikan inklusi harus bisa mewujudkan dan memelihara kelas agar nyaman, menerima keanekaragaman, dan perbedaan. Dalam hal tersebut guru bertanggungjawab menciptakan kelas yang dapat menjadi wadah bagi semua peserta 
didik secara utuh stanpa membeda-bedakan perbedaan. Kurikulum yang diterapkan adalah kurikulum reguler yang dimodifikasi atau dikembangkan sesuai dengan kebutuhan anak-anak berkebutuhan khusus (Sopandi, 2013, p. 2).

Meskipun metode pembelajaran di SDLB merupakan kombinasi dari berbagai metode namun menyampaian materi PAI tidak banyak menggunakan metode ceramah atau menerangkan, melainkan mencontohkan dengan gerakan, dengan gmabar visual atau video, membimbing secara langsung dalam praktek. Sebagaiamana observasi peneliti dalam pembelajaran materi wudu di kelas 6 SDLB Sunan Kudus ketika akan melaksanakan salat Zuhur. Guru kelas berwudu pertama kali dan memperlihatkannya kepada para peserta didik, sedangkan guru pendamping mengondisikan agar pesera didik memperhatikan. Kemudia peserta didik maju untuk praktek wudu 1 (satu) per 1 (satu) dengan dikondisikan oleh guru pendamping, sedangkan guru kelas memperhatikan peserta didik yang sedang praktek wudu. Jika ada yang salah maka guru membenarkan, dan jika ada yang belum bisa mandiri melakukan wudu sendiri maka guru membimbingnya (Peneliti, Observasi, 10 Februari 2020).

Kepala Sekolah SDLB Sunan Kudus mengungkapkan bahwa materi hanya sebagai penunjang, sedangkan materi yang diutamakan adalah kemandirian, interaksi sosial, dan kebiasaan anak, seperti ketika peserta didik mendengar azan mereka segera menuju masjid, biasa berdoa ketika mereka akan makan, ketika bertemu dengan guru atau orang lain mereka bersalaman (Kristianto, Wawancara, 11 Maret 2020).

Berdasarkan analisis terhadap hasil dokumentasi terhadap perangkat pembelajaran di kelas besar SDLB Sunan Kudus, kurikulum pembelajaran yang diterapkan mengikuti standar sekolah dasar menggunakan pendekatan tematik sesuai kurikulum yang ditetapkan pemerintah dalam Peraturan Pemerintah Nomor 32 Tahun 2013, pasal 1 ayat 16, dan sudah dimodifikasi agar sesuai dengan kemampuan dan memenuhi kebutuhan peserta didik autis (Peneliti, Dokumentasi, 12 Maret 2020). Hal ini dilakukan dengan tujuan untuk menyesuaikan kondisi peserta didik yang memiliki beberapa gangguan yang menjadi kendala dalam pembelajaran, sebagaimana disebutkan dalam Dewi dan lainnya yang menjelaskan bahwa peserta didik autis memiliki gangguan kemampuan komunikasi dan interaksi sosial (Dewi et al., 2018, p. 290-292).

Adapun kegiatan inti di kelas terapis berdasarkan hasil wawancara, pembelajaran di SDLB Sunan Kudus menyesuaikan kebutuhan anak-anak autis karena mereka memiliki tingkatan kemampuan yang berbeda-beda. Pembelajaran dilaksanakan dengan menerapkan pendekatan individual dan metode pembelajaran stimulus-respon yang dilakukan dengan cara mengulang-ulang materi pembelajaran (Setyaningsih, Wawancara, 11 Maret 2020). 
Berdasarkan wawancara dengan Kepala SDLB Sunan Kudus, pembelajaran di kelas besar berakhir pada pukul 13.00 (satu siang) WIB. Pada akhir pembelajaran guru kelas mengajak peserta didiknya untuk mengucapkan kalimat alhamd lillah rabb al'älamīn secara bersama-sama dan memberikan penilaian mengenai pembelajaran yang telah berlangsung dengan cara bertanya kepada peserta didik, kemudian mengajak peserta didik bersalaman dengan guru secara urut secara bergiliran (Kristianto, Wawancara, 11 Maret 2020). Pembelajaran di kelas terapis tidak berbeda dengan pembelajaran di kelas reguler, menurut guru terapis dalam wawancara yang dilakukan peneliti berakhir setiap 1 jam sekali dan diakhiri dengan memberikan penilaian dengan mengacu pada form penilaian materi individu (Setyaningsih, Wawancara, 11 Maret 2020).

\section{Evaluasi Pembelajaran PAI pada Anak Autis}

SDLB Sunan Kudus menggunakan evaluasi proses dan evaluasi produk pada mata pelajaran PAI. Hal tersebut sesuai dengan hasil observasi terhadap kegiatan pembelajaran di kelas 6 SDLB Sunan Kudus, yaitu selama proses kegiatan belajar mengajar guru kelas memperhatikan peserta didik dan membuat catatan mengenai tingkah laku setiap peserta didik (Peneliti, Observasi, 6 februari 2020). Sedangkan pelaksanaan evaluasi produk sesuai dengan observasi peneliti pada tes praktik wudu, yaitu guru mengajak peserta didik untuk berwudu secara bergantian dan kemudian guru mencatat perkembangan setiap peserta didik. Di antara beberapa peserta didik terdapat peserta didik yang sudah mampu berwudu sendiri, ada yang masih perlu bimbingan, dan ada pula yang harus dituntun langkah demi langkah (Peneliti, Observasi, 10 februari 2020). Berdasarkan penjelasan guru di kelas besar SDLB Sunan Kudus dalam wawancara oleh peneliti, evaluasi proses dilaksanakan dengan cara pengamatan setiap saat selama pembelajaran berlangsung. Bentuk penilaian yang diberikan adalah penilaian dalam bentuk angka dan penilaian berbentuk catatan deskriptif yang direkap dalam catatan-catatan perkembangan yang terdapat dalam jurnal harian guru. Kemudian rekapan yang sudah dibuat digunakan sebagai acuan dalam merencanakan pembelajaran pada peserta didik dalam 1 minggu berikutnya. Sedangkan evaluasi produk dilaksanakan terstruktur dan tidak terstruktur. Evaluasi produk terstruktur dilakasanakan sesuai jadwal akademik dan evaluasi produk tidak terstruktur dilaksanakan setiap hari, yaitu melalui tes lisan yang berupa tanya jawab secara langsung dan tes tertulis (Charisma, Wawancara, 21 Januari 2020). Hal tersebut sesuai dengan Widyawati bahwa evaluasi pada anak autis terdiri dari evaluasi input, evaluasi proses, dan evaluasi produk (Widyawati, 2017, p. 115-117). 
Hal tersebut sudah memenuhi standar yang telah ditetapkan Pemerintah dalam Permendikbud Nomor 22 tahun 2016, bahwa pendekatan dalam meklakukan evaluasi pembelajaran standarnya menggunakan penilaian otentik (authentic assesment). Keterpaduan antara penilaian kesiapan peserta didik, proses pembelajaran, dan hasil belajar akan menghasilkan dampak instruksional pada aspek pengetahuan dan dampak pengiring pada aspek sikap. Hasil penilaian yang di berikan setiap seminggu sekali dijadikan sebagai bahan acuan penyusunan pembelajaran pada 1 minggu berikutnya, sebagai salah satu kegiatan tindak lanjut.

\section{Produk Manajemen Pembelajaran PAI pada Anak Autis}

Berdasarkan hasil tes wawancara yang dilakukan peneliti terhadap beberapa peserta didik autis, SDLB Sunan Kudus mampu menciptakan peserta didik autis yang hafal surat-surat pendek, dapat memimpin tahlil dan doa tahlil (Peserta Didik, Wawancara, 3 Desember 2020). Dan berdasarkan observasi pada tes praktik wudu dan salat zuhur, SDLB Sunan Kudus mampu menciptakan peserta didik autis yang dapat berwudu dengan mandiri secara urut dan benar, serta dapat melaksanakan salat berjamaah dan mampu menjadi imam (Peneliti, Observasi, 10 Februari 2020). Hal tersebut dibuktikan dengan observasi dan wawancara peneliti kepada beberapa peserta didik autis di SDLB Sunan Kudus, beberapa peserta didik mampu menunjukkan hasil yang dicapai dengan memraktikkannya di hadapan peneliti.

Mudjito dalam Widyawati menjelaskan bahwa ada 4 aspek yang menjadi tuntutan dalam pelaksanaan pendidikan, yaitu kognitif yang bertumpu pada daya serap dan nalar terhadap materi pembelajaran, psikomotorik yang mencakup bakat dan keterampilan, soft skill yang meliputi intra dan inter-personalitas, perilaku terhadap diri sendiri, sesama makhluk, dan Tuhan, dan karakter yaitu membentuk hard skills dan soft skills (Widyawati, 2017, p. 117).

Dari pembahasan di atas efektivitas manajemen pembelajaran PAI di SDLB Sunan Kudus ditunjukkan dengan analisis peneliti terhadap hasil dokumentasi perangkat pembelajaran dan observasi peneliti terhadap kegiatan belajar mengajar di kelas 6 SDLB Sunan Kudus, serta wawancara yang dilakukan peneliti dengan guru kelas dan kepala SDLB Sunan Kudus yang memperoleh hasil bahwa penyusunan perangkat pembelajaran dilakukan setiap seminggu sekali. Hal tersebut efektif diterapkan dalam pembelajaran PAI pada anak autis karena pembelajaran harus dilaksanakan sesuai dengan kondisi mereka yang dapat berubah-ubah dalam waktu yang cepat. Penyusunan perangkat pembelajaran didasarkan pada hasil evaluasi selama 1 minggu sebelumnya. Evaluasi yang dilakukan setiap waktu selama pembelajaran berlangsung dan dilakukan perekapan setiap seminggu sekali, karena hasilnya lebih aktual dan sinkron melihat 
kondisi anak-anak autis yang berubah-ubah. Hasil evaluasi digunakan sebagai acuan untuk menyusun perencanaan 1 minggu berikutnya. Hanya saja, kurikulum yang diterapkan bukan kurikulum individual, kurikulum individual hanya diterpakan di kelas kecil (kelas tambahan), sedangkan kondisi peserta didik autis memiliki perbedaan yang sangat variatif antara 1 dengan yang lainnya, baik tingkat kecepatan penyerapan materi, konsentrasi, kepatuhan, maupun kemandiriannya sehingga peserta didik autis membutuhkan program pembelajaran individual, maka perencanaan pembelajaran harus disusun secara individu dengan mengacu pada hasil pembelajaran setiap harinya. Dengan kata lain, setiap peserta didik mendapatkan perencanaan pembelajaran sendirisendiri dan pelaksanaan pembelajaran sendiri-sendiri. Sebagaimana penjelasan Mardiana bahwa dalam pembelajaran inklusi hanya sebagian kecil dari peserta didik di kelas yang mampu mengikuti proses pembelajaran yang disebabkan oleh keterbatasan kemampuan, oleh karena hal tersebut peserta didik autis membutuhkan program khusus, yaitu Program Pembelajaran Individual (PPI). PPI merupakan proses belajar mengajar dengan cara membimbing secara khusus pada setiap individu yang membutuhkan perlakuan khusus untuk mengembangkan kemampuan secara optimal (Mardiana et al., 2020, p. 180). Oleh karena tidak diterapkannya PPI di kelas reguler di SDLB Sunan Kudus,guru mengalami kesulitan dalam mengaplikasikan perencanaan ke dalam pelaksanaan pembelajaran karena terkadang yang direncanakan tidak dapat diterapkan pada setiap peserta didik autis.

Efisiensi manajemen pembelajaran dibuktikan dengan hasil analisis terhadap observasi terhadap kegiatan belajar mengajar di kelas 6 SDLB Sunan Kudus dan wawancara dengan Kepa Sekolah, guru di kelas reguler, dan guru di kelas terapis SDLB Sunan Kudus yang menunjukkan bahwa penggunaan metode ABA dalam pembelajaran di SDLB Sunan Kudus, yaitu dengan cara membiasakan peserta didik memraktekkan materi PAI yang dimasukkan dalam setiap pembelajaran dengan panduan atau instruksi dari guru. Materi yang diajarkan disederhanakan sesuai dengan kebutuhan dan kemampuan anak-anak autis, seperti berdoa setiap mengawali kegiatan, menyanyikan lagu-lagu yang memuat materi PAI, dan datang ke masjid ketika mendengar azan. Pemilihan metode ini sangat tepat diterapkan pada peserta didik autis yang susah diajak berpikir abstrak agar melatih peserta didik mandiri melaksanakan kegiatan yang diajarkan dalam pembelajaran PAI, sehingga tidak memakan banyak waktu sedangkan hasilnya nihil. Hal tersebut sesuai dengan hasil penelitian Jessy dan Diswantika yang menunjukkan bahwa metode ABA memperoleh respon positif. Dengan metode ABA, setiap rangsangan yang diberikan terapis ditanggapi oleh peserta didik autis dan dinilai dalam bentuk penghargaan untuk kemajuan perkembangan. Metode ABA lebih 
menekankan pada pelatihan kontak mata, motorik kasar, mengikuti instruksi sederhana, serta memahami informasi visual (Jessy \& Diswantika, 2019, p. 107-108)

Produktivitas manajemen pembelajaran dilihat dari data yang diperoleh dari wawancara dengan beberapa anak autis dan observasi terhadap pelaksanaan tes praktik wudu menunjukkan bahwa manajemen pembelajaran PAI di SDLB Sunan Kudus mampu menciptakan peserta didik autis yang mampu menghafal surat-surat pendek, dapat memimpin tahlil dan doa tahlil, dapat berwudu dengan mandiri secara urut dan benar, serta dapat melaksanakan salat berjamaah dan mampu menjadi imam. Hal tersebut sesuai dengan Hanum yang menjelaskan bahwa efektifnya pembelajaran PAI pada anak autis dimulai dari hal yang kecil yang biasa dilaksanakan setiap hari atau sudah dilakukan di rumah bersama keluarga, serta mengajak peserta didik untuk mendapatkan fokus terhadap suatu objek tertentu (Hanum, 2014, p. 232).

\section{Simpulan}

Manajemen pembelajaran pada mapel PAI untuk anak autis di SDLB Sunan Kudus. Manajemen pembelajaran pada mapel PAI untuk anak autis di SDLB Sunan Kudus terdiri dari perencanaan pembelajaran PAI, pengorganisasian pembelajaran PAI, dan evaluasi pembelajaran PAI. Perencanaan pembelajaran pada mapel PAI untuk anak autis ditunjukkan dengan adanya penyusunan perangkat pembelajaran yang dilakukan dengan mempertimbangkan kondisi peserta didik autis setiap hari dan pada kelas kecil dibuat secara individu, pemilihan materi pembelajaran PAI yang dilakukan penyederhanaan dan penyesuaian terhadap karakteristik anak autis yang memiliki kelemahan perkembangan dan sulit dalam berpikir abstrak, serta adanya evaluasi yang direncanakan bersamaan dengan penyusunan perangkat pembelajaran sebagai instrumen dalam penilaian setiap hari. Pengorganisasian pembelajaran pada maoel PAI untuk anak autis dilakukan dengan mengorganisasikan sumber daya yang sudah disediakan sesuai kebutuhan anak autis, mengelola kelas yang dilakukan penyesuaian terhadap kondisi anak autis, serta mengorganisasikan kegiatan belajar mengajar yang merupakan penerapan dari perangkat pembelajaran. Evaluasi pembelajaran PAI di SDLB Sunan Kudus ditunjukkan dengan dilakukannya perencanaan evaluasi dan pelaksanaan evaluasi proses dan produk. Evaluasi proses dilaksanakan dengan cara pengamatan setiap saat selama pembelajaran berlangsung, serta dilakukan tindak lanjut dengan menyusun perangkat pembelajaran yang didasarkan pada evaluasi selama setiap seminggu sekali. Sedangkan evaluasi produk dilaksanakan secara terstruktur dan tidak terstruktur. Evaluasi produk terstruktur dilakasanakan sesuai jadwal akademik dan evaluasi produk tidak terstruktur dilaksanakan pada hari yang tidak ditentukan. 


\section{DAFTAR PUSTAKA}

Albab, H. A. U. (2015). Problematika Pembelajaran Pendidikan Agama Islam bagi Siswa Autis. AKADEMIKA, 9(2), 202-2015.

Ardina, R. (2018). Terapi ABA (Applied Behavior Analysis) Tingkat Dasar Efektif terhadap Perilaku Imitasi Aksi Anak Autis di Pusat Terapi LPSDM Graha Jiwa Indonesia Kab. Pringsewu. The Indonesian Journal of Health Science, 10(1), 8994.

Ballerina, T. (2017). Meningkatkan Rentang Perhatian Anak Autis dalam Pembelajaran Pengenalan Huruf. INKLUSI, 3(2), 245-266.

Dewi, R., Inayatillah, \& Yullyana, R. (2018). Pengalaman Orangtua dalam Mengasuh Anak Autis di Kota Banda Aceh. Psikoislamedia Jurnal Psikologi, 3(2), 288-301.

Efendy, H. (2018). Manajemen Pembelajaran dalam Penjaminan Mutu Pendidikan (Studi Multi Situs di SMA Negeri 1 dan SMA Negeri 3 Pamekasan). Jurnal Fikrotuna: Pendidikan Dan Manajemen Islam, 8(1), 1001-1010.

Erwinsyah, A. (2017). Manajemen Pembelajaran dalam Kaitannya dengan Peningkatan Kualitas Guru. TADBIR : Jurnal Manajemen Pendidikan Islam, 5(1), 69-84.

Garnida, D. (2015). Pengantar Pendidikan Inklusif (1st ed.). Refika Aditama.

Hanum, L. (2014). Pembelajaran PAI bagi Anak Berkebutuhan Khusus. Jurnal Pendidikan Agama Islam, 9(1), 217-236.

Jessy, M., \& Diswantika, N. (2019). Efektivitas Terapi Applied Behavior Analysis (ABA) terhadap Perkembangan Bahasa Anak Berkebutuhan Khusus Autisme. Jurnal Cakrawala Pendas, 5(2), 105-109.

Mardiana, A., Muzakki, I., Sunaiyah, S., \& Ifriqia, F. (2020). Implementasi Program Pembelajaran Indiviual Siswa Tunagrahita Kelas Inklusi. SITTAH: Journal of Primary Education, 1(2), 177-192.

Musdalifa, \& Panu, S. A. (2019). Implementasi Fungsi Manajemen Pembelajaran Berbasis Komputer di Sekolah Menengah. Meraja Jurnal, 2(1), 117-142.

Puspitasari, H. (2017). Standar Proses Pembelajaran sebagai Sistem Penjaminan Mutu Internal di Sekolah. Muslim Heritage, 1(2), 339-368.

Rahmahtrisilvia. (2010). Strategi Pembelajaran untuk Mengatasi Perilaku Tantrum pada Anak Autistik. Jurnal Ilmiah Ilmu Pendidikan, 10(2), 1-10.

Sopandi, A. A. (2013). Pengembangan Kurikulum bagi Siswa Berkebutuhan Khusus di SMK Negeri 4 Padang dalam Setting Pendidikan Inklusif. Jurnal Ilmiah Ilmu Pendidikan, 13(1), 1-9.

Suhendri. (2017). Manajemen Pembelajaran PAI bagi Anak Berkebutuhan Khusus di SLB Kota Medan. Sabilarrasyad, 2(2), 45-69. 
Thomas, P. (2011). Manajemen Pembelajaran di SMK Negeri 2 Semarang. Jurnal Pendidikan Ekonomi Dinamika Pendidikan, 6(1), 15-25.

Widyawati, R. (2017). Evaluasi Pelaksanaan Program Inklusi Sekolah Dasar. Kelola: Jurnal Manajemen Pendidikan, 4(1), 109-120.

Yulisetyaningrum, M., A. R., \& Alfijannah, I. Z. (2018). Hubungan Dukungan Sosial dengan Kemampuan Sosialisasi Anak Autisme. Jurnal Ilmu Keperawatan Dan Kebidanan, 9(1), 44-50. 